\title{
Compensation and Employee Loyalty Among Health Workers In Nigeria
}

\author{
Dr Omoankhanlen Joseph Akhigbe \\ Department of Management, Faculty of Management Sciences \\ University of Port Harcourt, Rivers State - Nigeria \\ Emmanuel Ethel Ifeyinwa \\ Department of Management, Faculty of Management Sciences \\ University of Port Harcourt, Rivers State - Nigeria
}

\begin{abstract}
Compensation and employee loyalty has been an issue of great concern in organizations over the years. This problem prevails in the contemporary society especially in Nigeria. It therefore becomes imperative to investigate and determine the influence of compensation on employee loyalty. The research was a survey of eight private hospitals that were purposively selected in Port Harcourt. To carry out this research, relevant literature was reviewed to confirm the existence of the problem. The components of the independent and dependent variables were examined. Questionnaire was the major instrument that was used to collect data for the study. The study sample size was determined using Taro Yamen's formula and Spearman Rank Order correlation coefficient was used to analyse the data. It was found that there is significant positive relationship between compensation and employee loyalty. It was recommended among others that regular payment of employees salary will impact positively on the cognitive loyalty of the employees. Increment of employee salary enhances positive reactions of the employees thereby inducing loyalty. Organizations should encourage the employees to own shares as it induces cognitive loyaltyamong workers. Equity based compensation influences employee behaviour positively thereby encouraging retention of employees. Organisations should consider occupational hazards of hospital environment when fixing the pay of the employees.
\end{abstract}

Keywords: Equity, Cognitive Loyalty, Behavioural Loyalty, Pay, Equity-based Compensation, Organizational Climate

\section{INTRODUCTION}

Today's business environment is characterized with competition, economic instability and turbulent changes in technology both at local and global level. The phenomenon of employee loyalty is on the increase in the recent time and it has become top priority in most organizations. This is as a result of its relevance not only in Nigeria but in the wider society. Most organizations do not want to lose their employees to rivals especially well talented and highly skilled employees. As a management concept, employee loyalty has attracted significant attention from many scholars who have researched on it from different backgrounds, (Rishipal\& Manish 2013).

Employee loyalty is imperative for organizational survival and prosperity. Researchers have demonstrated that faithful workers display abnormal state of emotional sense of duty regarding organizational success. Steadfast workers can be exceptionally significant advantages for the organizations as they can pick up as much benefits for the organizations. This is on account that steadfast workers will deal with clients in the correct manner and they comprehend what clients need and convey it. (Michlitsch 2000). The genuine achievement of an organization begins from workers readiness to utilize their innovative capacity and know- 
how for the organization and it is the organizations assignment to support and medical attendant this positive employees contribution by setting up viable reward rehearse, (Markorva\& Ford, 2011).

Today, healthcare organizations are tested by the absence of responsibility from nurses and doctors because of their decisions to leave the organization (Essono\&Sandeep 2016). Employee turnover can emerge accordingly disappointment at work, poor workplace and troublesome reward framework. At the point when the framework is no longer ideal to the employees, their loyalty starts to decay, negative work state of mind sets in, poor execution and at times prompts renunciation. This influences the efficiency, gainfulness and achievement of the organization. In this way any organization that needs to survive must set up an exceptionally viable reward framework, a standard pay structure and enhanced work approaches that are fit for improving worker viability and duty. Remuneration as a section of move between the worker and the proprietor that the results employee contract. As the forthcoming of employee, pay is the need of life. The payment gotten from work done in the business (Hameed, Ramzan, Zubair, Ali, \&Arslan, 2014).Organizations cannot manage without pay framework in light of the fact that the entire idea of work visitors on payment. It is a solid propelling element which upgrades or pushes execution. Pay as put by Upasana (2015) implies the places of pay level the extent that position or bent, underlining the places of compensation, the refinement and the standard of rank complexity. This calls for auditing of the agents as demonstrated by their level and capacities.

An aspect of management it can be depicted as the measure of reward that an expert foresees from the business. Delegates should be content with centered pay packs and they should be content with it while differentiating their remuneration bundles and those of the untouchables who are working in a comparable industry. A conclusion satisfaction is felt by accomplishing sensible and fair prizes (Alam, Rafat\&Puja, 2012). Compensate framework is one of the essential issues in each organization,if not well tailored and appropriately tended to, it can prompt debate, specialists distress or loses in the organization.

The subject of pay and Employee loyalty has dependably been a center administration issue in Nigeria as well as in more extensive society. This is available in all divisions of the economy both government parastatals and private area. The concentrate of this exploration is on remuneration as connected among healthworkers in Rivers State, Nigeria. The compensation framework is an exceptionally solid determinant in hierarchical execution. Martochio (2001) saw it as one part of a human asset framework and it is characterized as the prizes (fiscal and non-financial) that workers get for playing out their employments. It is a delicate segment of each administration.

\section{Statement of the Problem}

The loyalty and compliance of employees at work place is very important as it is the brain behind organizational survival. But the issue is that most employees seem not to be loyal to their companies. Research has shown that most organizations have record of theft, fraud, negative work attitude, absenteeism, strike and all forms of unethical behaviour. According toEssono and Sandeep (2016) attention to that the achievement of any organization starts from the eagerness of the employees to utilize their innovative capacities for the organization.

Compensation is a very vital element in human resources. It has direct bearing with performance, loyalty and environment. In the work of Cole (2005), he argued that the most important obligation owed by an employer to a worker is to pay him or her wages. The fulfillment of this duty involves most employers in the biggest expense of their business. In this 
circumstance therefore, it is not surprising that most organizations both private and public sector spend a good deal of time and effort in devising appropriate payment systems to meet all these various pressures.

Compensation is a fundamental issue in every organization because it boarders basically on the payment of the employees. It is viewed as a crucial segment of the human resource because of its sensitivity, it is pure employee matter and as such most organizations handles it with pinch of caution. It is in this line that Nantaet al., (2010) argued that organizations both public and private design compensation packages and strategies to increase employees job satisfaction and job performance.

Nevertheless, despite the seemingly high premium of compensation, most organizations still record high labour turn over especially in the focused area of this research, the health sector. The major issues regarding local or international private organizations have increasingly high rate of staff turnover and the ineffective performance caused by various issues such as poor salary, complex environment, ambiguous duties, job insecurity and most importantly few orientation as well as required on the off job trainings desirable to execute the take efficiently (Batool\&Batool 2012). Most work organizations especially in the health sector which is the focus area of this study should probably identify compensation as the key component of effective organization. It is necessary to carry out this study to investigate compensation as it applies in organizations. Hence, supporting those individuals who are loyal and committed will strengthen the bond between the organization and employees (Fischer, 2013).

This study is set to investigate the basic issues that borders on compensation as it affects employee loyalty in work organization especially the health sector in Rivers State, Nigeria.

\section{Conceptual Framework}

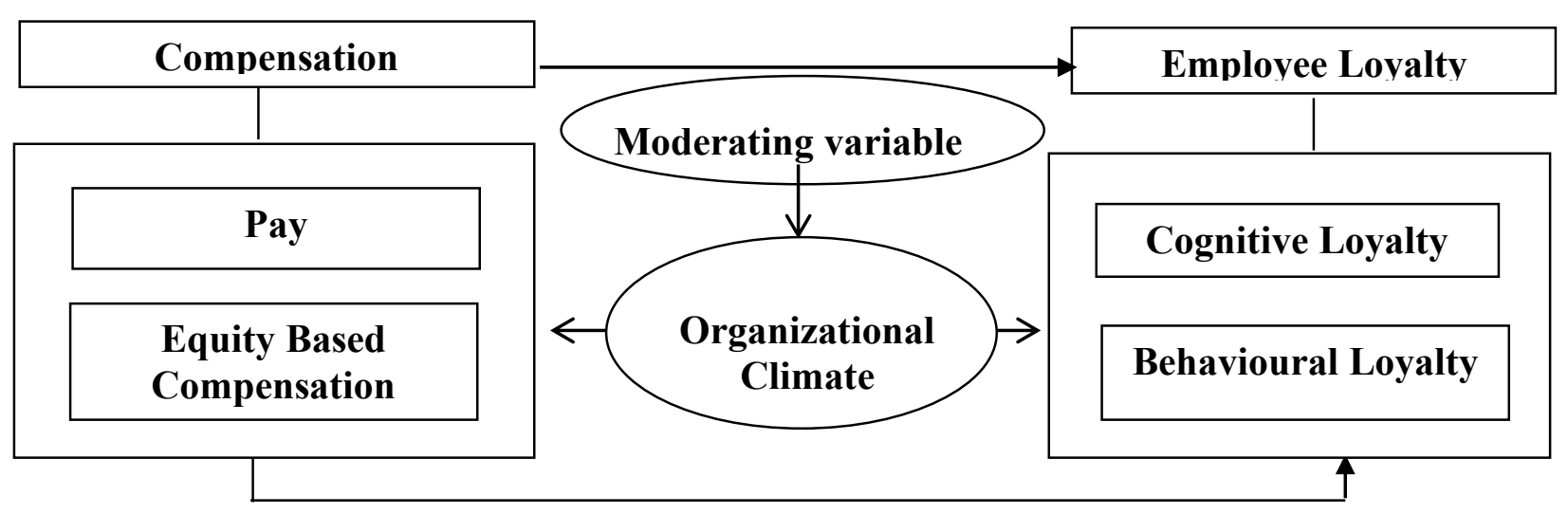

Fig. 1: Conceptual Framework showing the relationship between compensation and employee loyalty.

The dimensions for compensation are pay and equity based compensation (Stock) option were adapted from Aswath (2005). The measures for employee loyalty are cognitive and behavioural loyalty were adapted from Mohammed \&Mahsa (2015).

\section{Objectives of the Study}

In specific terms, this study objective is as follows:

i. To examine the relationship-between pay and cognitive loyalty of health workers in Rivers State, Nigeria, Nigeria. 
ii. To examine the relationship-between pay and behavioural loyalty of health workers in Rivers State, Nigeria.

iii. To examine the relationship-between equity based compensation (stock) and cognitive loyalty of health workers in Rivers State, Nigeria.

iv. To examine the relationship-between equity based compensation (stock) and behavioural loyalty of health workers in Rivers State, Nigeria.

v. To determine how organizational climate moderate the relationship between compensation and employee loyalty of health workers in Rivers State, Nigeria.

\section{Research Hypotheses}

The study hypotheses are:

Ho1 There is no significant-relationship between pay and cognitive loyalty of health workers in Rivers State, Nigeria.

$\mathrm{Ho}_{2}$ There is no significant-relationship between pay and behavioural loyalty of health workers in Rivers State, Nigeria.

$\mathrm{Ho}_{3}$ There is no significant-relationship between equity based compensation (stock) and cognitive loyalty of health workers in Rivers State, Nigeria.

$\mathrm{Ho}_{4}$ There is no significant-relationship between equity based compensation (stock) and behavioural loyalty among health workers in Rivers State, Nigeria.

$\mathrm{Ho}_{5}$ Organisational climate does not significantly moderate the relationship between compensation and employee loyalty of health workers in Rivers State, Nigeria.

\section{Scope of the Study}

It explains the coverage of the study in terms of content scope, geographical scope and unit of analysis.

\section{Content Scope:}

The knowledge was restricted to literature in compensation, employee loyalty, pay, equity based compensation, cognitive loyalty, behavioural loyalty and organisational climate.

\section{Geographical Scope:}

The study was conducted in Rivers State, Nigeria.

Unit of Analysis: The unit of analysis is micro and that is based on individual level.

\section{Theoretical Framework}

\section{LITERATURE REVIEW}

The theoretical foundation of this study is the theory of equity in compensation. The theory of equity in compensation has attracted much attention over decades ago. Equity theory was first propounded by John Stacy Adams in 1963. He argues that an employee is mainly concerned with whether his benefit or reward (pay) is equal to his level of input or effort at work, Adams (1963). The emphasis is on determining whether the distribution of resources is fair to the partners involved.

Equity theory point that an individual's motivation is affected by how he or she perceives inputs (i.e. work performance to outcomes (i.e. rewards) in relation to referent others. Consequently, from a motivational perspective, the organization must provide rewards that are proportionate to individual inputs. (Gomez-Mejia, Berrone\& Franco-Santos 2010). Equity theory depends on the recommendation that individuals make judgements about the reasonableness of their compensation on a near premise. Individuals in a similar occupation part, doing comparative work under a compensation movement framework dictated by issues, 
for example, legitimacy or examination, will make an evaluation with respect to regardless of whether the exertion remunerate results are reasonable (Thompson, 2000).

As indicated by Heinz, Mark and Koontz (2011), equity theory focuses on whether people see the reward as being reasonable or about the reasonableness of the reward he or she gets, in respect to the data sources which incorporates many variables, for example, exertion, experience and training in correlation with the prizes of others. The idea of equity theory is focusing on how workers feel about pay in a specific organization contrasted with that of their partners in different organizations. They look at their commitments which constitute inputs and the yields the benefit and relate it to their compensation. The tenate of equity theory is that the compensation of aemployee ought to be equivalent to his commitment to the organization. Adams (1963) in his work on Toward an Understanding of Inequity he called attention to that worker view of what they add to the organization, what they receive consequently and how their arrival commitment proportion thinks about to other inside and outside the organization decides how reasonable they see their business.

This theory holds the view that when employees watch a few components or measures of disparity in their compensation framework, they will surely attempt to right it, this is the thing that prompts work agitation in both work services and corporate organizations. It is toward this path that Redmond (2010) contends that equity theory recommends that a man's inspiration depends on what he or she considers to be reasonable when contrasted with others.

Gogia (2010) called attention to that equity theory concentrates on anemployee's work remuneration relationship or trade relationship and additionally that of employees endeavor to limit any feeling of injustice that may come about. Equity idea is investigated by numerous researchers as a fundamental instrument of inspiration which has solid impact in employee execution. At the point when employees are not generously compensated contrasted with their information, the propensity is that they will see it as disparity and obviously battle to reestablishequity. They can choose to go on strike or start to demonstrate non-challant state of mind towards their occupation or working with irritation. This obviously will influence the perfeormance of the organization.

Equity theory gives a helpful guide as remuneration capacity. It can be connected in any trade circumstance, so there are large numbers of parts that can be recorded as information sources or yields (Redmond 2015). As Geshart, Minkoff\& Olsen (1995) put it that Equity theory is likewise pertinent in light of the fact that it can be connected to pretty much any compensation choice since decency is dependably a key concern.

\section{Compensation}

In every business organization, the pay system is always a crucial issue. This is probably because it is seen as strong determinant of employee loyalty and performance. As a management concept, compensation can be described as the core of any employment exchange and it serves as a defining characteristic of any employment relationship (Glassman, Champagne \&Zugelder 2010).Compensation does not exist in a vacuum. At a very basic level an organisation's compensation system reflects a reasoned strategy in the part of organization is going to compete within a competitive and constantly changing workplace (Maloa 2011).

Agwu (2013) brought up that the central reward for performing work is pay, numerous businesses likewise offer reward bundles of which wages and pay rates are just a section. The 
bundles commonly incorporate rewards, benefits, plans, medical coverage, distributed autos, helpful advances financed dinners, benefit sharing, share choices, and so forth. Upasana (2015) defined compensation as the stages of position or skill. Studies have shown that compensation structure also includes grading of the employees according to their qualifications and functions. It is expected that the salary and allowances will certainly differ. There are some key points that require consideration.

Table 1: Compensation Structure

\begin{tabular}{|l|l|l|l|}
\hline 1 & Pay structure & Job performance & Ability to perform \\
\hline 2 & Employer's focus & $\begin{array}{l}\text { Job carries wages, link to } \\
\text { job. }\end{array}$ & $\begin{array}{l}\text { Employee carries } \\
\text { wages, }\end{array}$ \\
\hline 3 & Employee focus & $\begin{array}{l}\text { Job promotion to earn } \\
\text { greater pay }\end{array}$ & $\begin{array}{l}\text { Skill acquisition to } \\
\text { earn greater pay. }\end{array}$ \\
\hline 4 & Procedure required & $\begin{array}{l}\text { Access job content; equity } \\
\text { job. }\end{array}$ & $\begin{array}{l}\text { Access skills; equity } \\
\text { skills. }\end{array}$ \\
\hline
\end{tabular}

Adapted from: Upasana (2015)

\section{Pay Compensation}

One of the pay compensation is traditional method of remuneration. It is the oldest system of exchange. No organization can survive without remuneration of the human resources. The primary need for work is pay. It is in this light Geshart, Minkoff\& Olsen (1995), contended that employees ordinarily rely on upon wages, pay rates to give an expansive offer of their salary and on advantages to give wage and health security. The essence of this compensation is to empower the workers meet their day by day needs. Keeping in mind the end goal to pick up accomplishment in getting and holding a strong work compel, business as are centering their exertion more towards addressing the requirements of desire of their employees (Acrue partners, 2016). Organizations contrast in strategies, approach and administration style. As indicated by Geshart, Minkoff\& Olsen (1995), they propelled that compensation rehearses shift essentially crosswise over utilizing units and to some degree, crosswise over occupations. Sometimes, the nature of the occupation decides the compensation, in the work of Mechmood (2013), he called attention to that prizes assume crucial part in expanding employee rewards and change the conduct of disappointed workers.

\section{Equity Based Compensation (Stock) Option}

Everywhere throughout the world, the conventional instrument of reward framework is cash payment. Be that as it may, in the current decades consideration has moved to equity based compensation particularly among present day organizations. There is presently acknowledged that enhancing executives' long termincentives is attractive (Lucian \&Yesse 2010).

Equity based compensation has turned into a greater piece of general worker pay. As of late, many firms have moved towards equity based pay for their workers. It is normal for firms to give a large number of alternatives every year to top directors as well as to lower level chiefs (Aswath 2005).

Most contemporary organizations embrace the act of equity based compensation and for the most part investment opportunity as a result of its advantages. Owning stocks in the organizations can make the workers to have that sentiment possession which at last forms into organizational citizenship conduct (OCB). Most organizations make equity based compensation beat need as it helps organizations to accomplish the level of corporate administration and accomplish organizational goals. 
Current organizations and in addition the healthsector embrace the act of equity based pay and incorporate it with their compensation structure particularly the investment opportunity on account of the conspicuous advantages. As indicated by Aswalth (2005), offering equity in the firm to supervisors may decrease the office issue by making administrators think more like stockholders as most equity pay accompanies a necessity that the worker remain with the firm for a timeframe (the resting time frames) to make a case for the remuneration. Workers who get choices or limited stock as remuneration are in this way more prone to remain with a firm.

This arrangement of payment supports maintenance and employee unwaveringness among the workers. Equity motivating forces and stock based pay are vital components of the contracting condition amongst shareholders and administrators (John, Guay\& David 2003). In stock based compensation the workers are being remunerated with loads of the organization. In this arrangement of remuneration, the stock turns into the instrument of payment. Stock however can be alluded to as an offer in the responsibility for organization. Stock speaks to a claim on the organization's benefits and income. The more an official gets more stock, in his in the organization increments (John, Guay\& David, 2003). It is a method for empowering the workers and compensating their execution in the organization through that solid instrument of compensation.

\section{Employee Loyalty}

The idea of employee loyalty has dependably been a pivotal issue in each work put. Organizations that comprehend management standards and values dependably endeavor to guarantee employee faithfulness in the organization. Hooi (2013) sees employee loyalty as a mental connection or a pledge to the organization and creates increasedfulfillment. Fulfillment comes about because of a procedure of interior assessment and if a worker's desire level is met or surpassed, then fulfillment develops. Employee dedication then forms into a summed up passionate demeanour towards the organization. At the end of the day, the more fulfilled a employee is with respect to his or her workplace, the more probable that he or she will build up a feeling of responsibility towards the organization when all is said in done.

The effect of qualities, objectives and goals of the organization on Employee loyaltycanbe very surprising. Most employees incline toward an inviting workplace to extensive administration. In this way loyalty is portrayed by the solid wish to proceed with participation of an organizationwhich assumes a positive part in maintenance of individuals in the organization Becker, Donna \&Riegel (1995).

\section{Cognitive Loyalty}

Cognitive loyalty is an important aspect of employee loyalty. It is the first stage in the loyalty model of management (Mohammed \&Mahsa, 2015). It is another aspect of loyalty identified in more recent years which viewed loyalty as a higherlevel dimension and involves the employees' conscious decision making process in the evaluation of alternatives (Caruana 2002). Under cognitive loyalty, employees are rational in their belief and logical in their decisions. Their loyalty is based on what they will gain. Employees are conscious of their input in the organizations and compare it with their pay. They try to find out if their pay is commensurate to their input (Ndanusa, Harada, Romle\& Abdul 2015).

As a component of loyalty, employees with cognitive loyalty can easily shift their service to another company. This occurs when there is an organization that can give them a better offer. This is because under cognitive loyalty, there is no deep loyalty to the organization, too much attachment or allegiance. It is in this direction that Kalyanaram, Gurumurthy, John\& Little 
(1994) argued that most employees are born to switch to another organization once they perceive alternative offerings which are more beneficial.

\section{Behavioural Loyalty}

The loyalty of the employees is always uppermost to the employer. Every organization strives to make employees are loyal. Maznah, Yusoff\&Hussin (2010) asserted that it has become top priority in most organizations because of its immense positive impact towards organizational survival. Noah \& Steve, (2012) asserted that it makes sense to study and know about attitudes because strong attitudes will very likely affect a person's behaviour.

According to Noe, Hollenbeck, Geshart\& Wright (2006) the competitive business environment has triggered significant attention of many researchers in the area of behavioural loyalty. The human resource management of most organizations are thinking of the strategies, practices and frameworks that impact employees conduct, states of mind and execution. As indicated by Geise and Cote (1999) fulfillment can either be a behavioral or psychological reaction relying upon the specific circumstance. As a social being, employee cannot easily be predicted. Organizations that are not sensitive about the behavioural component might experience labour unrest.

\section{Organizational Climate}

Organizational climate portrays how employees see specific attributes of their utilizing organization which incorporates authority style, correspondence level and the workers' cooperation in the basic leadership (Essono\&Sandeep, 2016). It alludes to the essential segments inside the organization which fundamentally affect the workers.

Adenike (2011) propelled that hierarchical climate involves related arrangements of states of mind, values and practices that describe the individuals from a specific organization.

In this review, the organizational climate under survey is health sector in Rivers State, Nigeria Healthcare where specialists which is thought to be most perilous work related settings, (Moore \&Karmerel 1990).

Most organizations including the health sector expect high level of loyalty and committed from their employees. Employees on the other hand expect the enabling environment and conditions that can guarantee satisfaction to make them deliver quality services. But most health organizations play down on this. The health risks prevalence at workplace are sufficient reasons that necessitates constant demand for improved remunerations, adequate provisions of safety materials to protect the health worker and favourable policies and safety laws. The life and safety of the health worker should be given top priority.

\section{Relationship between Compensation and Employee Loyalty}

Compensation portrays payment of the employees by the organization for the service rendered. Remuneration is the center of each work trade and it fills in as a characterizing normal for any business relationship (Glassman, Champagne \&Zugelder 2010). The issue of remuneration is one of the fundamental parts of business that an organization must settle before getting the employees. The primary reward for performing work is pay, numerous businesses additionally offer reward bundles of which wages and pay rates are just a section. The bundles ordinarily incorporate rewards annuity plans, advances, sponsored dinners benefit sharing, medical coverage, allotted autos, share alternatives and a great deal more (Agwu 2013). 
Remuneration ought to be outlined remembering the way of the occupation and all that is included so that sufficient arrangements can be made. Employees regularly rely on upon wages, pay rates to give a vast offer of their salary and advantages to give pay and health security (Geshart, Minkoff\& Olsen 1995).

Clearly the outline of the pay decides the work state of mind of the employees which has a considerable measure to do with loyalty. At the point when the remuneration is not great, it results to poor work state of mind and work turn over. Today's social insurance organizations are tested by the absence of duty from medical attendants and specialists because of their decision to leave the organization (Essono\&Sandeep 2016).

The main non-monetary parameter that influences worker loyalty is job satisfaction. Work satisfaction is a mind boggling state of mind which includes certain suspicions and convictions about the occupation (a psychological part), sentiments towards work (a full of feeling segment) and the work appraisal, (an assessment segment). A fulfilled specialist is a beneficial labourer and the organization's prosperity cannot be accomplished having disappointed workers (Igor, Buntak\&Ivana, 2015). The relationship is that of tit for tat. Williams et. al., (2007) declared that if employees are happy with how the organization works and imparts its remuneration arrangements, they stay focused on the organization. Organization's reward framework can influence the execution of the employee and their yearning to stay utilized (Bamberger \&Meshouam 2000).

At the point when a company receives an arrangement of reward that is useful to the workers, the impact is that the employee end up noticeably faithful and furthermore builds their level of duty consequently guaranteeing high efficiency and productivity. On the other hand, whereby the pay is not good to the person, the inverse is the situation; the organization starts to witness negative work state of mind, truancy, robbery, dillydallying, extortion, acquiescence, and so forth. No big surprise (Gomez-Mejia, Berrone, and Franco-Santos 2010) declared that when execution is utilized as a reason for disseminating rewards, payment is accommodated individual or gathering commitments to the firm. Remuneration conveys payment for the yield or result and most intently looks like the operation of conventional piece-rate arrangements or deals commissions. As indicated by Bevelacqua\& Singh (2009), pay-for-execution frameworks are as often as possible utilized by organizations with an end goal to connection remuneration to enhanced worker execution.

\section{Empirical Review}

Hooi(2013) investigated employee loyalty at workplace with focus on the impact of Japanese style of Human Resource Management. As indicated by Hooi (2013), loyalty is a mental connection or sense of duty regarding the organization and creates subsequently of expanded fulfillment. He included that aemployee who has built up a full of feeling to the organization will probably show steadfast practices and work towards the general objectives of the organization. He watched that worker loyalty is high in organizations that practice great working relationship, inspiration and great workplace. It energizes cerebrum pick up and debilitates mind deplete.

Mohammad \&Mahsa (2015) researched on stages of loyalty as a psychological attachment to a company or selected brand which is often in the form of a long term and on-going relationship with the brand. They explained the concept of loyalty as it develops from single stage to four stage loyalty. The three dimensional loyalty are cognitive, behavioural and affective loyalty the fourth dimensional include conative loyalty. Good knowledge of loyalty is important as it 
enhances understanding of how to deal with employees at work place or customers of a brand product.

Upasana (2015) inquired about on impact of pay on employee loyalty to organization and characterized employee loyalty as how well the staff are loyal to the organization, having a sentiment holding, consideration, care, obligation and commitment towards it, including that it can be depicted as the degree to which there is a general readiness among employees to make a speculation or faculty yield for the benefit of the organization. He portrayed pay as a composed practice that includes adjusting the work worker connection by giving financial and non-money related advantages to employee. It helps in propelling the employees and enhancing organizational adequacy. He watched that today business condition is quick paced, corporate development, benefit and efficiency are basic, subsequently the need to bound and hold a group of faithful employees.

Loaloa, Labib\&Nawar (2016) surveyed the effect of organizational climate in employee commitment depicting climate as the moderately stable nature of an office situation experienced by people, impacting their practices and being founded on aggregate impression of individuals of the workplace. Organizational commitment as a basic worker state of mind is viewed as key segment in the organization. The review highlighted the significance of school climate and scholarly staff duty among workers of various levels.

Owie and Apanga (2016) in their work on word related health hazards winning among health works in creating nations characterized word related danger as the potential hazard to the soundness of a man rising up out of an undesirable domain which is a noteworthy medical problem. They watched that security of workers from business related scatters is not a need in many creating nations somewhat on the grounds that few other health related issues have contended with word related health. It was additionally watched that the administration of medicinal waste represents a high hazard to human services in creating nations, the review uncovered different types of normal word related health dangers that health specialists experience while giving consideration to customers in developing countries.

\section{Research Design}

\section{METHODOLOGY}

In this study, quasi-experimental research design was used. The reason is because the subject of this investigation is human being which cannot be subjected to laboratory experiment.

\section{Population of the Study}

The population of the study is 150 private hospitals in Rivers State, Nigeria but the accessible population is restricted to eight private hospitals in Port Harcourt. The choice for the selection of these eight hospitals is that they have existed over a decade, have related staff strength, have qualified health professionals, standard facilities and defined payment structure and pay roll. The category of health workers to be covered in this study includes the doctors, nurses, pharmacists, and laboratory technologists and they are 127.

\section{Sampling and Sample Size Determination}

In this study, simple random sampling was used. The reason for adopting this technique is to give every qualified member chance of being selected; Taro Yamen formula was also used for the selection of the participants. Therefore, the sample size of this work is 96. Also, to determine the minimum number of respondents for each hospital, Bowley's population allocation formula was used. 


\section{Methods of Data Analysis.}

In analyzing the data of this study, and testing the hypotheses, the Spearmen Rank Order Correlation Coefficient was used. While the partial correlation was used in testing the effect of the moderation role of organization climate on the predictor and criterion variable. The predictor variable is compensation and its dimensions are pay compensation and equity based compensation (stock). The dimensions and measures were measured using five (5) points measuring instrument.

Table 2: Population Allocation

\begin{tabular}{|c|l|c|c|}
\hline S/N & \multicolumn{1}{|c|}{ Hospital } & $\begin{array}{c}\text { No of } \\
\text { employees }\end{array}$ & Questionnaire Allocated \\
\hline 1. & Meridian Hospital & 15 & 11 \\
\hline 2. & New Mile I Hospital & 17 & 13 \\
\hline 3. & Palmas Hospital Ltd & 10 & 8 \\
\hline 4. & St. Martins Hospital & 23 & 17 \\
\hline 5. & Ebony Hospital & 17 & 13 \\
\hline 6. & Sonabel Medical Center & 12 & 9 \\
\hline 7. & Rehoboth Specialist Hospital & 8 & 6 \\
\hline 8. & Prime Medical & 25 & 19 \\
\hline & Total & $\mathbf{1 2 7}$ & $\mathbf{9 6}$ \\
\hline
\end{tabular}

Source: Survey Data 201

\section{Hypotheses Testing Results}

\section{Table 3: Test for Hypothesis 1}

Ho1 There is no significant-relationship between pay and cognitive loyalty of health workers in Rivers State.

Correlations

\begin{tabular}{|c|c|c|c|c|}
\hline & & & $\begin{array}{c}\text { Pay } \\
\text { Compensation }\end{array}$ & $\begin{array}{l}\text { Cognitive } \\
\text { Loyalty }\end{array}$ \\
\hline \multirow{6}{*}{ Spearman's rho } & \multirow{3}{*}{ Pay Compensation } & Correlation Coefficient & 1.000 & .171 \\
\hline & & Sig. (2-tailed) & & .027 \\
\hline & & $\mathrm{N}$ & 96 & 96 \\
\hline & \multirow{3}{*}{ Cognitive Loyalty } & Correlation Coefficient & .171 & 1.000 \\
\hline & & Sig. (2-tailed) & .027 & \\
\hline & & $\mathrm{N}$ & 96 & 96 \\
\hline
\end{tabular}

Source: SPSS Output 2017

The result of the analysis shows a significant level $p<0.05(0.027<0.05)$, rho $=0.171$. This means that there is a significant positive relationship between pay and cognitive loyalty. The null hypothesis is rejected.

\section{Table 4: Test for Hypothesis 2}

$\mathrm{Ho}_{2}$ There is no significant-relationship between pay and behavioural loyalty of health workers in Rivers State. 


\begin{tabular}{|c|c|c|c|c|}
\hline \multicolumn{5}{|c|}{ Correlations } \\
\hline & & & $\begin{array}{c}\text { Pay } \\
\text { Compensation }\end{array}$ & $\begin{array}{l}\text { Behaviour } \\
\text { al Loyalty }\end{array}$ \\
\hline \multirow{6}{*}{ Spearman's rho } & \multirow{3}{*}{ Pay Compensation } & Correlation Coefficient & 1.000 & .221 \\
\hline & & Sig. (2-tailed) & & .031 \\
\hline & & $\mathrm{N}$ & 96 & 96 \\
\hline & \multirow{3}{*}{ Behavioural Loyalty } & Correlation Coefficient & .221 & 1.000 \\
\hline & & Sig. (2-tailed) & .031 & \\
\hline & & $\mathrm{N}$ & 96 & 96 \\
\hline
\end{tabular}

Source: SPSS Output 2017

The result of the analysis shows a significant level $p<0.05(0.031<0.05)$, rho $=0.221$. This means that there is a significant positive relationship between pay and behavioural loyalty. The null hypothesis is rejected.

\section{Table 5: Test for Hypothesis 3}

$\mathbf{H o}_{3}$ There is no significant-relationship between equity based compensation (stock) and cognitive loyalty of health workers in Rivers State.

\section{Correlations}

\begin{tabular}{|c|c|c|c|c|}
\hline & & & $\begin{array}{c}\text { Equity Based } \\
\text { Compensation }\end{array}$ & $\begin{array}{l}\text { Cognitive } \\
\text { Loyalty }\end{array}$ \\
\hline \multirow{6}{*}{ Spearman's rho } & \multirow{3}{*}{$\begin{array}{l}\text { Equity Based } \\
\text { Compensation }\end{array}$} & Correlation Coefficient & 1.000 & .364 \\
\hline & & Sig. (2-tailed) & & .000 \\
\hline & & $\mathrm{N}$ & 96 & 96 \\
\hline & \multirow{3}{*}{ Cognitive Loyalty } & Correlation Coefficient & .364 & 1.000 \\
\hline & & Sig. (2-tailed) & .000 & \\
\hline & & $\mathrm{N}$ & 96 & 96 \\
\hline
\end{tabular}

Source: SPSS Output 2017

The result of the analysis shows a significant level $p<0.05(0.000<0.05)$, rho $=0.364$. This means that there is a significant positive relationship between equity and cognitive loyalty. The null hypothesis is rejected.

\section{Table 6: Test for Hypothesis 4}

$\mathrm{Ho}_{4}$ There is no significant-relationship between equity based compensation (stock) and behavioural loyalty among health workers in Rivers State.

\begin{tabular}{|c|c|c|c|c|}
\hline \multicolumn{5}{|c|}{ Correlations } \\
\hline & & & $\begin{array}{l}\text { Equity Based } \\
\text { Compensation }\end{array}$ & $\begin{array}{l}\text { Behaviour } \\
\text { al Loyalty }\end{array}$ \\
\hline \multirow{6}{*}{ Spearman's rho } & \multirow{3}{*}{$\begin{array}{l}\text { Equity Based } \\
\text { Compensation }\end{array}$} & Correlation Coefficient & 1.000 & .018 \\
\hline & & Sig. (2-tailed) & & .004 \\
\hline & & $\mathrm{N}$ & 96 & 96 \\
\hline & \multirow{3}{*}{$\begin{array}{l}\text { Behavioural } \\
\text { Loyalty }\end{array}$} & Correlation Coefficient & .018 & 1.000 \\
\hline & & Sig. (2-tailed) & .004 & \\
\hline & & $\mathrm{N}$ & 96 & 96 \\
\hline
\end{tabular}

Source: SPSS Output 2017

The result of the analysis shows a significant level $p<0.05(0.004<0.05)$, rho $=0.018$. This means that there is a significant positive relationship between equity and behavioural loyalty. The null hypothesis is rejected. 
Table 7: Moderating effect of Organizational Climate on the Relationship between Compensation and Employee Loyalty

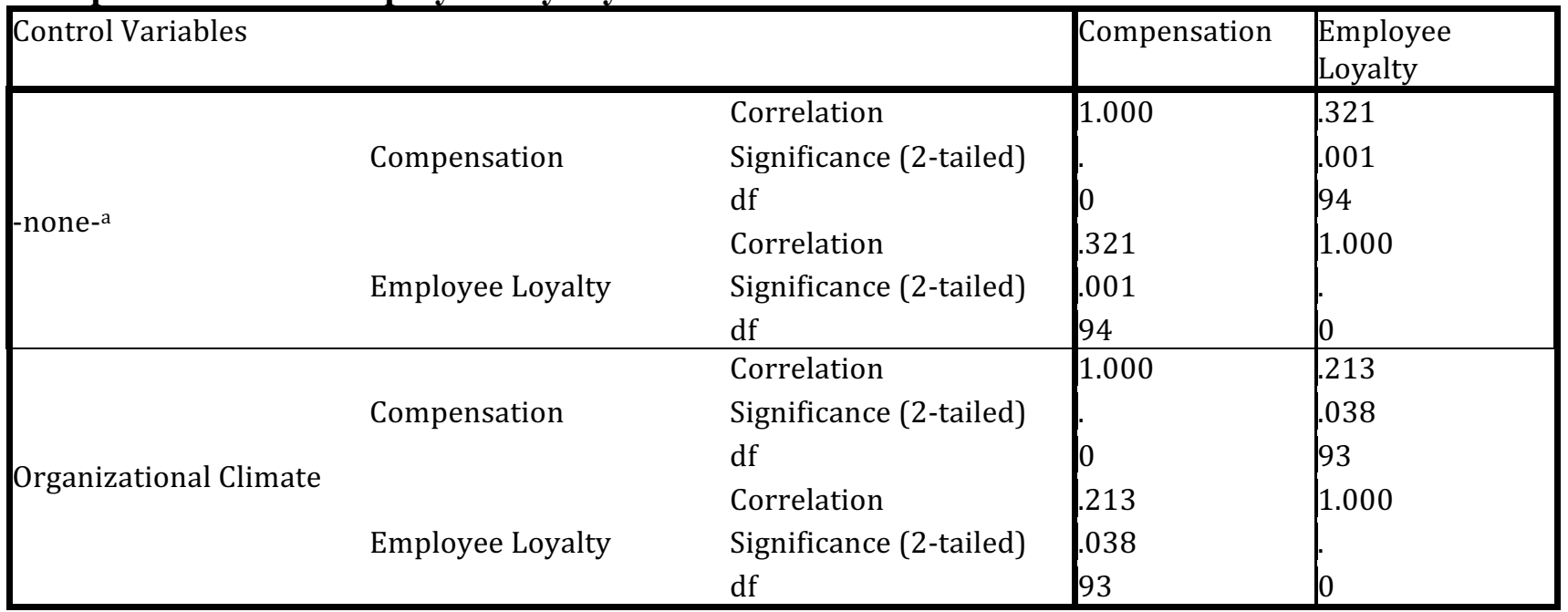

a. Cells contain zero-order (Pearson)

correlations.

\section{Source: SPSS Output 2017}

Table 7 shows the relationship between the independent and the dependent variable with and without the influence of a moderating variable. Without a moderating variable, the relationship between Compensation and Employee Loyalty is at a significant value $p=0.001$, and a correlation of rho $=0.321$. With the influence of a moderating variable (Organizational Climate), the significance still remains at $p=0.038$, at rho $=0.213$. The partial correlation analysis shows that Organizational Climate significantly moderates the relationship between the two variables. Therefore, the fifth null hypothesis, Organizational climate does not significantly moderate the relationship between compensation and employee loyalty of health workers in Rivers State, is rejected.

The result is based on correlations and it is a two-tailed, non-directional study. The Spearman's Rank Correlation was used to test the correlations and strength of relations. The partial correlation was used to test the moderating effect of Organisational Climate on the relationship between Compensation and Employee Loyalty. The decision rule is to reject the null hypotheses where $p<0.05$ significant level and accept the null hypotheses where $p>0.05$.

\section{DISCUSSION OF FINDINGS}

There is significant-relationship between pay and cognitive loyalty of health workers in Rivers State, Nigeria.

The results from table shows a significant level $\mathrm{p}<0.05(0.027<0.05)$, rho $=0.171$.This result shows a significant positive relationship between pay and cognitive loyalty. The null hypothesis is rejected. This is in line with the view of Geshart,Minkoft and Olsen (1995) that when employees are well paid, they perform better and are ready to stay in the organization. There is significant-relationship between pay and behavioural loyalty of health workers in Rivers State, Nigeria.

The result of the statistical analysis shows a weak positive relationship, while the significance level is 0.031 , the rho is 0.221 . Therefore the null hypothesis is rejected. This means that there is significant positive relationship between pay and behavioural loyalty. Employees can respond positively when their pay is improved. It is in this line that Noah and Steve (2012) 
pointed out the employees have the tendency to react towards supervision, pay, benefits, promotions or anything that might trigger positive or negative reactions. The employees will work towards the actualization of organizational objectives when they are well remunerated. The organization will also be sure of their loyalty.

There is significant-relationship between equity based compensation (stock) option and cognitive loyalty among health workers in Rivers State, Nigeria.

The statistical result shows a significant level of $\mathrm{p}<0.05(0.000<0.05)$ rho $=0.304$. This means that there is a significant positive relationship between equity based compensation (stock) option and cognitive loyalty. Contemporary organizations are shifting attention to this system of remunerations. This is different from traditional monthly salary system. By equity based compensation employees as rewarded with shares. This in effect gives them sense of belonging and right to vote during meetings. Equity incentives and stock based compensation are important features of the contracting environment between shareholders and executives (John, Guay and David 2003). It induces loyalty of the employees and enhances corporate governance.

There is significant-relationship between equity based compensation (stock) option and behavioural loyalty of health workers in Rivers State, Nigeria.

The result of the analysis shows a significant level $\mathrm{p}<0.05(0.005<0.05)$, rho $=0.018$. This result means that there is a significant positive relationship between equity based compensation (stock) option and behavioural loyalty. The null hypothesis is rejected, when the organizations allow the employees to own shares in the organizations, it gives the employees the opportunity to become shareholders. This influences the behavior of the employees positively hence to perform at efficiency level. It also encourages retention. Also, Lucian and Jesse (2010) pointed out the under a typical stock option plan, a specified number of options vests each year's work. Such vesting schedule encourages an executive to remain with the firm.

Moderating effect of organizational climate on the relationship between compensation and employee loyalty.

This analysis examines the moderating role of organizational climate on the relationship between compensation and employee loyalty. With the impact of organizational climate which is the moderating variable the level of significance is at $p=0.038$ while rho is 0.213 . From the partial correlation analysis, organizational climate significantly moderates the relationship of two variables which are compensation and employee loyalty. The null is rejected. In every organization, organizational climate includes policies, working environment, leadership and communication. Occupational hazards can be viewed as potential risks to the health of a person emerging from an unhealthy environment which is a significant public health issue (Owie\&Apanga 2016).

\section{CONCLUSION}

Putting our points together it has been established that compensation has strong influence on employee loyalty. Employees perform at efficiency level when they are effectively motivated. Apart from the monthly payment of salary which is conventional method of remuneration, employees can also be rewarded with stock option. This is a way of inducing loyalty among employees, hence making the employees to increase their productivity and being part of achieving organizational objective. When employees are properly rewarded, they are encouraged and also willing to stay with the organization. This encourages retention, 
discourages employee turnover and reduces loses in the organization.

\section{RECOMMENDATIONS}

From the data analysed and results obtained, the following recommendations are necessary to help solve the problems indentified.

- Regular payment of employees salary will impact positively on the cognitive loyalty of the employees.

- Increment of employee salary enhances positive reactions of the employees thereby inducing loyalty.

- Organizations should encourage the employees to own shares as it induces cognitive loyalty among workers.

- Equity based compensation influences employee behaviour positively thereby encouraging retention of employees.

- Organisations should consider occupational hazards of hospital environment when fixing the pay of the employees.

\section{References}

Adams J.S. (1963) Towards an Understanding of Inequity, Journal of Abnormal Psychology 67, 422-436.

Adenike A. (2011), Organizational climate as a Predictor of Employee Job satisfaction: Evidence from Covenant University. Business Intelligence Journal. 4:1. 155.

Adeturo T. (1986), Research Techniques for Project. New York, Prentice Hall.

Agwu M.O (2013) Impact of Fair Reward System on Employees job performance in Nigeria Agip Oil Company Ltd, Port Harcourt. British Journal of Education Society and Behavioral sciences. 3(1) 47-64.

Alam S. Rafat S. \& Puja A. (2012), Identification of variables affecting employee satisfaction and their Impact on the Organization. Journal of Business and Management. 15 (1),34

Aswath D. (2005), employee stock options (ESOPS) and restricted stock: valuation effects and consequences. Stern School of Business. 3 (1) 12

Bamberger D. A \&Meshouam I.S. (2000) Human Resource strategy, formulation and implementation. Business and Economics Review.4 (2) 9

Baridam D.M. (2008), Research Methods for Administrative Sciences, Port Harcourt, Sherbrooke Associates.

Batool A \&Batool B (2012), Effects of Employee`s training on the organizational competitive Advantage, Empirical study of private sector of Islamebad, Pakistan, for East Journal of Psychology and Business 6, (5) 72.

Becker T. E, Donna M.R \&Riegel C.D (1995), The multidimensional view of commitment and theory of reasoned Actions. A Comparative Evaluation.Journal of Management.21 (4), 26.

Bevelacqua C. M. \& Singh P. (2009). Pay for Performance - Panacea or Pandora's Box? Revisiting an old Debate in the Current Economic Environment, Compensation and Benefits Review.41:20.

Caruana, A. (2002). Service Loyalty, the effects of service quality and mediating role of customer satisfaction. European Journal of Marketing. 36(78), 811 - 829.

Cole G.A. (2005), Personnel \& Human Resources Management, Cornwall, T. J International Padstow.

Cuhadaraghu C, Erelel M, Tabak L. \&Kilicasian Z., (2002) Increased Risk of Tuberculosis in healthcare workers. A retrospective survey at a teaching Hospital in Istanbul, Turkey.B.M.C Infect Dis 2 (3) 14.

Eisenberger R, Ameni S, Rexwinkel B, Lyn P. D \& Rhodes L. (2001). Reciprocation of perceived organizational support.Journal of applied psychology 8 (6) 42-51.

Essono E.F \&Sandeep L.K (2016), Determinants of Employees commitment among Health Care Professionals. International Journal Academic research in Accounting Finance and Management sciences. 6 (2), 44.

Fischer R. (2013) Rewarding Employee loyalty: An organizational Justice Approach. International Journal of Organizational Behavior.8(3), 487. 
Fogleman S.L. \& McCorkle D. (2009) Risk management Education, Human Resource Management Employee Compensation Guide, Extension Agricultural Economist, Kansas State University, Texas A \& M.

Geise J.L \& Cote J.A (1999)- Defining customer satisfaction form http://www.amsreview.org/amsre/theory|geise 01-2000 pdf.

Geshart B. A, Minkoff H. B \& Olsen R.N. (1995), Employee Compensation; Theory practice and Evidence.Center for Advance Human Resource Studies.3 (5) 16-18

Ghadeer M.B (2015) Analyzing the antecedents of customer loyalty, British Journal of Marketing Studies. 3 (5) , 3448.

Glassman A, Champagne P.J \&Zugelder M.T. (2010), Evaluating Pay-for Performance Systems: Critical Issues for Implementation. Compensation and Benefits Review 4 (2) 231.

Gogia P. (2010) Equity theory of motivation. Retrieved from http//www.businesshub.com/equity theory of motivation. 6 (4) 12-13

Gomez-Mejia L, Berrone P, \& Franco-Santos M, (2010), Compensation and Organisational Performance: Theory, Research and Practice. M.E. Sharp Inc.

Gostic A \& Elton C. (2009). The carrot principle, New York: Free Press.

Hameed A, Ramzan M, Zubair H.K., Ali G, \&Arslan M. (2014), Impact of Compensation on Employee Performance (Empirical evidence from Banking sector Pakistan. International Journal of Business and Social Science, 5 (2), 302.

Heinz W, Mark V.C. \& Koontz H. (2011). Management. New Delhi, India. Tata McGraw Hill Education Private Limited.

Hooi, L.W. (2013). Emoloyee Loyalty at the Workplace: The Impact of Japanese Style of Human Resource Management. International Journal of Applied HRM, 3(1), 2

Igor K., Buntak K. \&Ivana D, (2015), Employee Loyalty: Difference between genders and the Public and the Private sector. Interdisciplinary description of complex systems. 14(3), 303-313.

Jesudas C.D \&Thengakunam B. (2013) Tuberculosis Risk in Healthcare Worker: Indian journal of Chest Disease and Allied Science 5 (5) 149-154.

John E.C, Guay W.R \& David F.L (2003), Executive Equity compensation and incentives: a survey. FRBY Economic policy Review, 2 (2) 50.

Kalyanaram G. \& John D.C. Little (1994) An Empirical Analysis of Latitude of Price Acceptance in Consumer Package Goods, Journal of Consumer Research 21(3) 408 - 419.

Loaloa R, LabibA\&Yehia S.N (2016), Assessing the Impact of Organizational climate on employees commitment. The business and management review. 7 (3), 358

Lucian A. B and Jesse M. F (2010).How to Tie Equity Compensation to Long Term Results.Journal of Applied Corporate Finance, 22(1), 99

Lussier A. N.(1997) Management. Crimination Western College Publisher.

Maloa F. (2011). Determinants of Employee Compensation in an Organization.Resource Article.University of South Africa. 7 (3) 34

Markova G. \& Ford C. (2011). Is money the package? Reward for knowledge workers. InternationalJournal of Productivity and Performance Management.60 (89), 813-823

Martochio J.J. (2001), Strategic Compensation: A Human Resource Management Approach, Upper Saddle River N.J. Pearson.

Maznah W. O, Yusoff K. \&Hussin, H. (2010). Employee motivation and its Impact on Employee loyalty.World Applied Sciences Journal 8. 8(7), 371

Michlitsh, J.F. (2000), High Performing, Loyal Employee: The Real way to implement strategy. Journal of Strategy and Leadership,2 (2) 33.

Mohammad J.T and Mahsa M.B (2015), Loyalty: from single-stage loyalty to four stage loyalty: International Journal of New technology and Research. 1(6), 49.

Ndanusa M.M, Harada Y, Romle A.R., \& Abdul S.S. (2015), cognitive, affective and conative Loyalty in Higher Education Marketing: Proposed Model for Emerging Destination. International Review for Management and Marketing. 3 (5) 28 
Noah Y. \& Steve M. (2012). Work Environment, Job Attitude among Employees in a Nigerian Work Organisation. Journal of Sustainable Society, 1(2), 36 - 43.

Noe R.A., Hollenbeck J.R., Geshart B. \& Wright P.M (2006) Human Resources Management, fifth Edition, Mcgraw hill Irwin, New York, America.

Nwankwo O.C. (2013), A Practical Guide to Research for Student of Research enterprise. University of Port Harcourt Press Ltd., Port Harcourt.

O'sears D, Freedman J.L \&Peplan L.A (1985) Sowal Psychology, fifth edition, NJ Prentice Hall Inc, Engle wood cliffs. $7(8), 1$

Owie H. 0 and Apanga P.A (2016), Occupational health Hazard Prevailing Among healthcare Workers in Developing Countries.Journal of Aids and Clinical research. 4 (2) 25

Redmond B. F. (2010), Lesson 5; Equity Theory, is what I get for my work fair compared to others? Work attitudes and motivation. The Pennsylvania State University World Campus. 4 (2) 17

Rishipal, M. \& Manish A. (2013). Performance Management and Employee Loyalty.Global Journal of Management and Business Research Administration Management. 13(3), 24

Thompson M. (2000), The Competitiveness challenge: The Bottomline, Benefits of strategic Human Resources. D.T.I. 6 (2) 8

Upasana K.M (2015), Influence of compensation on Employee Loyalty to organization. Asian Journal of Multidisciplinary Studies.3(2), 195.

World Health Organization (2016) International Statistical classification of diseases and related health problems (ICD -10) in occupational health. 